\title{
Genetics of Orange, Red and Yellow Root Colours in Tropical Carrots (Dacus Carota L.)
}

\author{
Raman Selvakumar ( $\sim$ selvakumarsingai@gmail.com ) \\ Indian Agricultural Research Institute \\ Dalasanuru Chandregowda Manjunathagowda \\ Directorate of Onion and Garlic Research https://orcid.org/0000-0002-1506-7633 \\ Pritam Kalia \\ Indian Agricultural Research Institute
}

Research Article

Keywords: Chi-square test, Dominant gene, Inheritance, F2, Backcross

Posted Date: February 12th, 2021

DOI: https://doi.org/10.21203/rs.3.rs-189778/v1

License: () (1) This work is licensed under a Creative Commons Attribution 4.0 International License. Read Full License 


\section{Abstract}

The research was carried out to study the colour inheritance genetics of the root epidermis, core (phloem) and cortex (xylem), from the parental crosses of the varieties Pusa Meghali (Orange), Pusa Rudhira (Red) and Pusa Kulfi (Yellow). Resultant in crosses yielded uniform mixed colours in $F_{1}$ (first filial generation), thus could enhance the security of human nutrition through the mixture of carotenoids and anthocyanins in the $F_{1}$. The $F_{1} s$ were advance to produce $\mathrm{F}_{2}$ and backcross $\left(\mathrm{BCP}_{1}\right.$ and $\left.\mathrm{BCP}_{2}\right)$ generations, and the Chi-square test ratio $\left(\mathrm{x}^{2}\right)$ showed that the root colour of the orange epidermis and cortex (xylem) was dominant over the red and yellow colours, and regulated by dominant genes Oe and Ocx from the parent Pusa Meghali. While, the root colour of the orange core (phloem) was found to be recessive to the red $(R c)$ from Pusa Rudhira and yellow $(Y c)$ colour from Pusa Kulfi, and to be regulated by a single recessive gene (oc) from the parent Pusa Meghali. These finding of genetic inheritance of colours would be useful in the development of bio-fortified $F_{1}$ hybrids and varieties which are rich in flavonoids.

\section{Introduction}

Carrot (Dacus carota L.) first definitive mention as a root crop around 1100 years in central Asia, orange carrots first sighted in southern Europe during 15th century (Stolarczyk and Janick 2011), and red carrots noted Asia in 17th century (Rubatzky et al. 1999; Simon 2000). Orange colour cultivars are predominant in carrots, and cultivars were developed in Europe since from the 16th century (Banga 1963). Carotenoids have been a distinctive feature of carrots, and the colours of carrots were stated either orange and yellow or purple (Banga 1957, 1963; Simon 2000). Wild carrots contain traces of carotenoids, while cultivated carrots contain at most carotenoids (Arscott and Tanumihardjo 2010). Carotenoids are a valuable source of dietetic vitamin A and are a variety of carrot roots of orange, red, and yellow colour, their biosynthesis, development and accumulation differ with diverse environmental and genetic contexts, the carotenoid biosynthetic genes upregulation in carrots yield the high carotenoid content. The interaction of $Y$ and $Y_{2}$ genes contribute for the variation of carotenoids in white, yellow, and orange carrots, Orgene association with carotenoids of carrot has been acknowledged, and discovery of genes which are contributing to the carotenoids biosynthesis pathway have an exciting consequence for carotenoids rich carrot improvement (Simon et al. 2019). Due to the inability of de novo synthesis of carotenoids, humans are aware of the nutritional value of carotenoids, dietary carotenoids ( $\alpha$-carotene, $\beta$-carotene, $\beta$-cryptoxanthin, lycopene and lutein) converted to vitamin $A$, which is important for cancer and cardiovascular risk reduction, for the maintenance of immunity, growth and reproduction (Tanumihardjo 2012). The major carotenoids are lutein contributes to the yellow root colour, a-and b-carotene contribute to the orange root colour, and lycopene produces the red colour. (Arscott and Tanumihardjo 2010). Orange carrots contain trace amounts of phytoene, f-carotene, lutein and lycopene (Grassmann et al. 2007; Nicolle et al. 2004; Simon and Wolff 1987), red carrots produce a- and b-carotene, lutein, and lycopene (Arscott and Tanumihardjo 2010; Grassmann et al. 2007), high carotenoid content noted from orange, yellow, and red colour roots (Wang et al. 2014)

Carrot colours were first noted by carrot breeders to reference the cross with wild carrots (white root) during carrot breeding (Vilmorin 1859), cultivated white and yellow carrots intercrosses revealed the white root colour was dominant to yellow root colour (Borthwick and Emsweller 1933; Emsweller et al. 1935), yellow root colour dominant over orange root colour, which was governed by a single dominant gene (Emsweller et al. 1935; Lamprecht and Svensson 1950), orange root colour dominant over red coloured root from the crosses between orange and red coloured carrots, $F_{2}$ and backcross populations showed the two genes $A$ and $L$ were conditioned for lycopene and a-carotene content in progeny (Katsumata et al. 1966). The carrot root colour has been controlled by several genes, white root colour dominant over yellow colour carrot through single dominant gene, the segregation ratios from the crosses between white and orange colour parents yielded white, orange and yellow progenies in $\mathrm{F}_{2}$, $\mathrm{F}_{3}$ and backcrosses fitted in two to three gene patterns of inheritance depending on the population (Laferriere and Gabelman 1968; Imam and Gabelman 1968). Kust (1970) named the white colour controlling single gene $Y$ dominant over yellow root colour, and additional two dominant genes $Y_{1}$ and $Y_{2}$ were revealed from white and orange crosses, the dominant alleles in the crosses white $\times$ yellow, white $\times$ orange and yellow $\times$ orange revealed low carotenoids contents (Laferriere and Gabelman 1968). Natural orange carrot mutant was conditioned by a recessive gene noted as $r p$, reduces root $\alpha$-, $\beta$-carotene, and $a$-tocopherol content with high phytoene content, and $r p$ gene associated with reduced plant vigour, a unique carrot gene associated with carotenoid colour (Goldman and Breitbach 1996; Koch and Goldman 2005). The high heritability of total carotenoid content $(0.89-0.98 \%)$ noted for the B493 $\times$ QAL, and low heritability was noted from the Brasilia $\times \mathrm{HCM}(0.38$ to 0.45$)$, this indicated $Y$ and $Y_{2}$ genes largely influence on the cross B494 $\times$ QAL population, and the variability of carotenoids content among the population influence on the environments (Perrin et al. 2016, 2017), the allelic variation for the Orgene observed mainly in the centre of diversity of carrots from Central Asia than the European carrots (lorizzo et al. 2013). The orange carrot ( $y y y_{2} y_{2}$ ) and wild yellow carrot (Orw) have a homozygous condition of the cross, thus the heterozygotes are light orange ( $\left.\operatorname{OrcOrcyyy}_{2} \mathrm{y}_{2}\right)$, the variation for $\mathrm{Orgene}$ evolved during early carrot domestication at Central Asia from wild Orcallele (Simon et al 2019). In $\mathrm{F}_{2}$ population of red $\times$ white crosses intricate a new tinge yellow-red colour phenotype with a high content of total carotenoids in xylem than the phloem, more variability of pigments found in $\mathrm{F}_{2}$ populations of red $\times$ yellow and red $\times$ white and yet genetics of this phenotype not known (Buishand and Gabelman 1980). In the context of root epidermis, root cortex and root colour inheritance studies were not done so far, hence we have undertaken the study to investigate the inheritance orange, yellow and red colours, since carrot root epidermis, core and cortex colour varied with a single colour to mixed colours, studies are limited and lacking on tropical carrot colour inheritance, thus the genetics of colour inheritance of root epidermis, core and cortex of carrot-based on the systemic colour classification using RHS mini colour chart (RHS 2005), these research findings will be helpful in the development of tropical carrot varieties and $\mathrm{F}_{1}$ hybrids.

\section{Materials And Methods}




\section{Plant materials}

The inbred lines of Pusa Asita (purple colour), Pusa Rudhira (red colour), Pusa Kulfi (yellow colour) and Pusa Meghali (orange colour) with a single colour of epidermis, core and cortex were developed in Division of Vegetable Science, Indian Agricultural Research Institute, New Delhi, India. $F_{1}{ }^{s}$ (first filial generation) were developed by the crosses inbred lines during 2012-2013, $F_{1}$ 's were selfed and produced $F_{2}$ generations, and backcrosses were developed by crossing both the parents to the corresponding $F_{1}$ 's during 2014-2015. The $F_{2}$ and back cross $\left(\mathrm{BCP}_{1}\right.$ and $\left.\mathrm{BCP}_{2}\right)$ population were used for assessment of carrot root colour inheritance.

\section{Carrot root epidermis, core and cortex colour classification and genetics of inheritance}

The field grew carrot plants were harvested by uprooting and washed the roots of different populations (Parents, $F_{1}, F_{2}$ and Backcross), then the carrot roots were sliced for standard colour evaluation, root colours were evaluated based on Royal Horticultural Society mini chart 2005 (RHS 2005 ), the root colours were classified and classification is given in Table 1, and the genetics of root colour inheritance was assessed using RHS colour classification. Root epidermis, core and cortex colour of classified $\mathrm{F}_{2}, \mathrm{BCP}_{1}$, and $\mathrm{BCP}_{2}$ population were analyzed by Chi-square $\left(\chi^{2}\right)$ tests for goodness of fit using plant breeders tools (PBT 2005) software which was developed by International Rice Research Institute, the test ratios of phenotypes evaluated were compared with 3:1 for the $\mathrm{F}_{2}$, and 1:1 for the $\mathrm{BCP}_{1}$ and $\mathrm{BCP}_{2}$ generations respectively.

Table 1

Colour grouping according to the Royal Horticultural Society Mini-Colour Chart (2005)

\begin{tabular}{|c|c|c|}
\hline RHS Code & Colour Chart & Root Colour \\
\hline \multirow[t]{2}{*}{ RHS-N79A } & & Red Purple \\
\hline & & (Dark Purple Red) \\
\hline \multirow[t]{2}{*}{ RHS-59B } & & Rose Purple \\
\hline & & (Dark Brown) \\
\hline \multirow[t]{2}{*}{ RHS-187A } & & Black Purple \\
\hline & & (Dark Purple) \\
\hline \multirow[t]{2}{*}{ RHS-N77B } & & Grey Purple \\
\hline & & (Dark Brown) \\
\hline RHS-32B & & Orange Red \\
\hline RHS-33A & & Light Red \\
\hline \multirow[t]{2}{*}{ RHS-31A } & & Orange Pink \\
\hline & & (Medium Orange Pink) \\
\hline \multirow[t]{2}{*}{ RHS-34C } & & Medium Red \\
\hline & & (Orange Red) \\
\hline \multirow[t]{2}{*}{ RHS-23C } & & Yellow Orange \\
\hline & & (Medium yellow Orange) \\
\hline RHS-24A & & Medium Orange \\
\hline RHS-25A & & Light Orange \\
\hline \multirow[t]{2}{*}{ RHS-29C } & & Orange Pink \\
\hline & & (Medium Orange Pink) \\
\hline \multirow[t]{2}{*}{ RHS-2C } & & Yellow Green \\
\hline & & (Light Yellow Green) \\
\hline RHS-1D & & Light Yellow \\
\hline RHS-4B & & Medium Yellow \\
\hline \multirow[t]{2}{*}{ RHS-9B } & & Yellow \\
\hline & & (Medium Yellow) \\
\hline
\end{tabular}




\section{Results And Discussion}

\section{Inheritance genetics of epidermis, cortex and core root colours}

The $\mathrm{F}_{1}$ hybrids were developed between orange (Pusa Meghali), red (Pusa Rudhira) and yellow (Pusa Kulfi) root coloured carrots had orange epidermis and cortex in the combination of red and yellow root core, and there were no maternal effects were found on epidermis and cortex root colours from the parents of reciprocal crosses. This could be due to the dominant gene action of orange root epidermis (Oe) and cortex (Ocx) contributed from the inbred parent Pusa Meghali, and root core colour influenced by the dominant genes Rc from Pusa rudhia and $Y_{C}$ from Pusa Kulfi. The orange carrot $\left(y_{y} y_{2} y_{2}\right)$ and wild yellow carrot (Orw) have the homozygous condition of a cross, thus the heterozygotes are light orange (OrcOrcyyy $\left.y_{2} y_{2}\right)$, the variation for Orgene evolved during early carrot domestication at Central Asia from wild Orc allele (Simon et al 2019). The single dominant genes governing traits are valuable assets in the exploitation of heterosis for root yield enriched with high carotenoids content.

The segregation of the $\mathrm{F}_{2}$ population of the cross Pusa Meghali (Orange root) $\times$ Pusa Rudhira (Redroot), the backcross population of (Pusa Meghali $\times$ Pusa Rudhira) $\times$ Pusa Meghali $\left(\mathrm{BCP}_{1}\right)$ and (Pusa Meghali $\times$ Pusa Rudhira) $\times$ Pusa Rudhira $\left(\mathrm{BCP}_{2}\right)$, and the $\mathrm{F}_{2}$ population of the cross Pusa Rudhira $\times$ Pusa Meghali, the backcross population of (Pusa Rudhira $\times$ Pusa Meghali) $\times$ Pusa Rudhira $\left(B_{1} \mathrm{CP}_{1}\right)$, (Pusa Rudhira $\times$ Pusa Meghali) $\times$ Pusa Meghali $\left(\mathrm{BCP}_{2}\right)$ population presented in Table 2, the test ratio was fitted in the goodness of Chi-square test revealed the orange epidermis $(O e)$ and cortex $(O c x)$ colour dominant over red (re, rcx) colour with the genetics of inheritance governed by single dominant gene pattern for the orange epidermis and cortex colour of carrot root. Whereas the orange root core $(o c)$ colour was recessive to the red $(R c)$ colour, test ratio findings showed that the orange core colour of the root was regulated by the single recessive gene (Fig. 1), orange root colour dominant over red coloured root from the crosses between orange and red coloured carrots, $\mathrm{F}_{2}$ and backcross populations showed the two genes $A$ and $L$ were conditioned for lycopene and a-carotene content in progeny (Katsumata et al. 1966). Natural orange carrot mutant was conditioned by a recessive gene noted as $r p$, reduces root $a-$, $\beta$-carotene, and atocopherol content with high phytoene content, and $r p$ gene associated with reduced plant vigour, a unique carrot gene associated with carotenoid colour (Goldman and Breitbach 1996; Koch and Goldman 2005). In $F_{2}$ population of red $\times$ white crosses intricate a new tinge yellow-red colour phenotype with a high content of total carotenoids in xylem than the phloem, more variability of pigments found in $F_{2}$ populations of red $\times$ yellow and red $\times$ white and yet genetics of this phenotype not known (Buishand and Gabelman 1980). Interestingly, the characteristic coexistence of yellow and orange colour in the roots, the colour assorted in different root sections with unique stoichiometry could be assigned to different parents in the genetic backgrounds was fairly explained by simple inheritance for root epidermis, cortex and core colour of carrot root of the inbred parents Pusa Meghali and Pusa Rudhira. 
Table 2

Root colour segregation and inheritance of population developed from Pusa Maghali and Pusa Rudhira

\begin{tabular}{|c|c|c|c|c|c|c|c|c|c|c|c|c|c|}
\hline \multicolumn{14}{|c|}{ Pusa Maghali $\left(P_{1}\right) \times$ Pusa Rudhira $\left(P_{2}\right)$} \\
\hline Population & Traits & $\begin{array}{l}\text { Yellow } \\
\text { Orange }\end{array}$ & $\begin{array}{l}\text { Medium } \\
\text { Orange }\end{array}$ & $\begin{array}{l}\text { Light } \\
\text { Orange }\end{array}$ & $\begin{array}{l}\text { Orange } \\
\text { Pink }\end{array}$ & $\begin{array}{l}\text { Orange } \\
\text { Red }\end{array}$ & $\begin{array}{l}\text { Light } \\
\text { Red }\end{array}$ & Orange & Red & Total & $\begin{array}{l}\text { Test } \\
\text { Ratio }\end{array}$ & $\chi^{2}$ & $\mathrm{P}$ \\
\hline $\mathrm{F}_{2}$ & Epiderm & 106 & 71 & 52 & 92 & 39 & 69 & 321 & 108 & 429 & $2.97: 0.34$ & 0.00 & 0.93 \\
\hline $\mathrm{BCP}_{1}$ & Epiderm & 23 & 11 & 10 & 18 & 18 & 39 & 62 & 57 & 119 & 1.09:0.92 & 0.21 & 0.64 \\
\hline $\mathrm{BCP}_{2}$ & Epiderm & 10 & 16 & 10 & 16 & 28 & 37 & 52 & 65 & 117 & $0.80: 1.25$ & 1.44 & 0.22 \\
\hline $\mathrm{F}_{2}$ & Cortex & 94 & 53 & 61 & 88 & 43 & 60 & 296 & 103 & 429 & $2.87: 0.35$ & 0.14 & 0.70 \\
\hline $\mathrm{BCP}_{1}$ & Cortex & 18 & 22 & 12 & 10 & 48 & 9 & 62 & 57 & 119 & 1.09:0.92 & 0.21 & 0.64 \\
\hline $\mathrm{BCP}_{2}$ & Cortex & 18 & 19 & 14 & 12 & 29 & 24 & 63 & 54 & 117 & $1.17: 0.86$ & 0.69 & 0.40 \\
\hline Population & Traits & $\begin{array}{l}\text { Orange } \\
\text { Red }\end{array}$ & $\begin{array}{l}\text { Light } \\
\text { Red }\end{array}$ & $\begin{array}{l}\text { Orange } \\
\text { Pink }\end{array}$ & $\begin{array}{l}\text { Medium } \\
\text { Red }\end{array}$ & $\begin{array}{l}\text { Yellow } \\
\text { Orange }\end{array}$ & $\begin{array}{l}\text { Medium } \\
\text { Orange }\end{array}$ & Orange & Red & Total & $\begin{array}{l}\text { Test } \\
\text { Ratio }\end{array}$ & $\chi^{2}$ & $\mathrm{P}$ \\
\hline $\mathrm{F}_{2}$ & Core & 99 & 97 & 62 & 94 & 67 & 60 & 127 & 352 & 429 & $0.36: 2.77$ & 0.58 & 0.04 \\
\hline $\mathrm{BCP}_{1}$ & Core & 18 & 14 & 13 & 13 & 43 & 18 & 61 & 58 & 119 & $\begin{array}{l}\text { 1.05: } \\
0.95\end{array}$ & 0.07 & 0.78 \\
\hline $\mathrm{BCP}_{2}$ & Core & 16 & 19 & 14 & 12 & 32 & 24 & 56 & 61 & 117 & $\begin{array}{l}0.92: \\
1.09\end{array}$ & 0.21 & 0.64 \\
\hline \multicolumn{14}{|c|}{ Pusa Rudhira $\left(P_{1}\right) \times$ Pusa Maghali $\left(P_{2}\right)$} \\
\hline Population & Traits & $\begin{array}{l}\text { Yellow } \\
\text { Orange }\end{array}$ & $\begin{array}{l}\text { Medium } \\
\text { Orange }\end{array}$ & $\begin{array}{l}\text { Light } \\
\text { Orange }\end{array}$ & $\begin{array}{l}\text { Orange } \\
\text { Pink }\end{array}$ & $\begin{array}{l}\text { Orange } \\
\text { Red }\end{array}$ & $\begin{array}{l}\text { Light } \\
\text { Red }\end{array}$ & Orange & Red & Total & $\begin{array}{l}\text { Test } \\
\text { Ratio }\end{array}$ & $\chi^{2}$ & $\mathrm{P}$ \\
\hline $\mathrm{F}_{2}$ & Epiderm & 117 & 78 & 57 & 63 & 42 & 65 & 315 & 107 & 422 & $2.94: 0.34$ & 0.02 & 0.86 \\
\hline $\mathrm{BCP}_{1}$ & Epiderm & 22 & 14 & 10 & 15 & 25 & 32 & 61 & 57 & 118 & $1.07: 0.93$ & 0.13 & 0.71 \\
\hline $\mathrm{BCP}_{2}$ & Epiderm & 23 & 15 & 10 & 11 & 20 & 35 & 59 & 55 & 114 & $1.07: 0.93$ & 0.14 & 0.70 \\
\hline$F_{2}$ & Cortex & 137 & 62 & 96 & 47 & 58 & 63 & 342 & 121 & 422 & $2.83: 0.47$ & 0.31 & 0.57 \\
\hline $\mathrm{BCP}_{1}$ & Cortex & 15 & 18 & 11 & 12 & 42 & 20 & 56 & 62 & 118 & $0.90: 1.11$ & 0.30 & 0.58 \\
\hline $\mathrm{BCP}_{2}$ & Cortex & 22 & 13 & 15 & 9 & 41 & 14 & 59 & 55 & 114 & $1.07: 0.93$ & 0.14 & 0.70 \\
\hline Population & Traits & $\begin{array}{l}\text { Orange } \\
\text { Red }\end{array}$ & $\begin{array}{l}\text { Light } \\
\text { Red }\end{array}$ & $\begin{array}{l}\text { Orange } \\
\text { Pink }\end{array}$ & $\begin{array}{l}\text { Medium } \\
\text { Red }\end{array}$ & $\begin{array}{l}\text { Yellow } \\
\text { Orange }\end{array}$ & $\begin{array}{l}\text { Medium } \\
\text { Orange }\end{array}$ & Orange & Red & Total & $\begin{array}{l}\text { Test } \\
\text { Ratio }\end{array}$ & $x^{2}$ & $\mathrm{P}$ \\
\hline $\mathrm{F}_{2}$ & Core & 98 & 77 & 64 & 69 & 54 & 60 & 114 & 308 & 422 & $\begin{array}{l}0.37: \\
2.70\end{array}$ & 0.91 & 0.33 \\
\hline $\mathrm{BCP}_{1}$ & Core & 19 & 12 & 16 & 10 & 37 & 24 & 61 & 57 & 118 & $\begin{array}{l}\text { 1.07: } \\
0.93\end{array}$ & 0.13 & 0.71 \\
\hline $\mathrm{BCP}_{2}$ & Core & 15 & 14 & 18 & 13 & 41 & 13 & 54 & 60 & 114 & $\begin{array}{l}0.90: \\
1.11\end{array}$ & 0.31 & 0.57 \\
\hline
\end{tabular}

The $\mathrm{F}_{2}$ segregates of the cross Pusa Kulfi (Yellow root) $\times$ Pusa Meghali (Orange root), the backcross population of (Pusa Kulfi $\times$ Pusa Meghali ) $\times$ Pusa Kulfi $\left(\mathrm{BCP}_{1}\right)$, (Pusa Kulfi $\times$ Pusa Meghali) $\times$ Pusa Meghali $\left(\mathrm{BCP}_{2}\right)$, and the $\mathrm{F}_{2}$ population developed from the cross Pusa Meghali $\times$ Pusa Kulfi, $($ Pusa Meghali $\times$ Pusa Kulfi) $\times$ Pusa Meghali $\left(\mathrm{BCP}_{1}\right)$ and (Pusa Meghali $\times$ Pusa Kulfi) $\times$ Pusa Kulfi $\left(\mathrm{BCP}_{2}\right)$ populations presented in Table 3 , the goodness of fit Chi-square test ratio revealed the orange epidermis $(O e)$ and cortex (Ocx) colour dominant over yellow (ycx) colour and governed by single dominant genes. Whereas, the orange root core $(o c)$ colour was recessive to the yellow core $(Y c)$ colour of root, and orange core colour of carrot root governed by the single recessive gene (Fig. 2). The segregating population of carrot crosses between red and yellow colour roots inferred three major genes, namely carotenoid synthesis inhibitor $\left(Y_{2}\right)$, lycopene synthesis stimulator $(L)$ and dominant gene responsible for $\beta$ - and a-carotene at the expense of lycopene could yield high orange colour root rich in carotenes resulted from red colour roots, furthermore the possible interaction of minor and modifier gene interactions, and two inhibitor genes $\left(Y\right.$ and $Y_{2}$ ) were segregated from the crosses between red and white colours, In $F_{2}$ population of red $\times$ white crosses intricate a new tinge yellow-red colour phenotype with high content of total carotenoids in xylem than the phloem, more variability of pigments found in $F_{2}$ populations of red $\times$ yellow and red $\times$ white (Buishand and Gabelman 1980), In the $F_{2}$ population of the cross red $\times$ white revealed two genes could have involved in the segregation of yellow colour progenies Kust (1970), the white color controlling single gene $Y$ dominant over yellow 
root clour, and additional two dominant genes $Y_{1}$ and $Y_{2}$ were revealed from white and orange crosses, the dominant alleles in the crosses white $x$ yellow, white $\times$ orange and yellow $\times$ orange revealed low carotenoids contents (Laferriere and Gabelman 1968). The allelic tests among inbreds (yellow root) yielded cent per cent yellow roots in the $\mathrm{F}_{2}$ population, with minimum white cores (PI175719 $\times$ PI220285). The $\mathrm{F}_{2}$ population of the cross PI173687 $\times$ Rheinische were all yellow rooted plants thus root colours governed by $Y_{2}$, because Rheinische segregant of $Y_{2} / Y_{2}$ (Buishand and Gabelman 1979), yellow root colour dominant over orange root colour, which was governed by a single dominant gene (Emsweller et al. 1935; Lamprecht and Svensson 1950), this indicated $Y$ and $Y_{2}$ genes largely influence on the cross B494 $\times$ QAL population, and the variability of carotenoids content among the population influence on the environments (Perrin et al. 2016, 2017). The co-occurrence of yellow and orange colour in the roots are the interesting traits, since the assortment of colour in the different root part with specific stoichiometry, could be attributed by different parents was relatively explicated simple genetic inheritance for root epidermis, cortex and core colour of carrot root in genetic backgrounds of Pusa Kulfi and Pusa Meghali parents.

Table 3

Root colour segregation and inheritance of population developed from Pusa Kulfi and Pusa Meghali

\begin{tabular}{|c|c|c|c|c|c|c|c|c|c|c|c|c|c|}
\hline \multicolumn{14}{|c|}{ Pusa Kulfi $\left(P_{1}\right) \times$ Pusa Meghali $\left(P_{2}\right)$} \\
\hline Population & Traits & $\begin{array}{l}\text { Yellow } \\
\text { Orange }\end{array}$ & $\begin{array}{l}\text { Medium } \\
\text { Orange }\end{array}$ & $\begin{array}{l}\text { Light } \\
\text { Orange }\end{array}$ & $\begin{array}{l}\text { Orange } \\
\text { Pink }\end{array}$ & $\begin{array}{l}\text { Yellow } \\
\text { Green }\end{array}$ & $\begin{array}{l}\text { Light } \\
\text { Yellow }\end{array}$ & Orange & Yellow & Total & $\begin{array}{l}\text { Test } \\
\text { Ratio }\end{array}$ & $x^{2}$ & $P$ \\
\hline $\mathrm{F}_{2}$ & Epiderm & 112 & 66 & 62 & 78 & 66 & 47 & 318 & 113 & 431 & $2.81: 0.36$ & 0.34 & 0.55 \\
\hline $\mathrm{BCP}_{1}$ & Epiderm & 23 & 12 & 16 & 14 & 20 & 34 & 65 & 54 & 119 & $1.20: 0.83$ & 1.01 & 0.31 \\
\hline $\mathrm{BCP}_{2}$ & Epiderm & 27 & 14 & 10 & 10 & 35 & 23 & 61 & 58 & 119 & $1.05: 0.95$ & 0.07 & 0.78 \\
\hline $\mathrm{F}_{2}$ & Cortex & 101 & 64 & 58 & 98 & 46 & 64 & 321 & 110 & 431 & $2.92: 0.34$ & 0.06 & 0.80 \\
\hline $\mathrm{BCP}_{1}$ & Cortex & 19 & 10 & 17 & 11 & 21 & 41 & 57 & 62 & 119 & $0.92: 1.09$ & 0.21 & 0.64 \\
\hline $\mathrm{BCP}_{2}$ & Cortex & 21 & 12 & 12 & 9 & 32 & 33 & 54 & 65 & 119 & $0.83: 1.20$ & 1.01 & 0.31 \\
\hline Population & Traits & $\begin{array}{l}\text { Yellow } \\
\text { Green }\end{array}$ & $\begin{array}{l}\text { Light } \\
\text { Yellow }\end{array}$ & $\begin{array}{l}\text { Medium } \\
\text { Yellow }\end{array}$ & Yellow & $\begin{array}{l}\text { Yellow } \\
\text { Orange }\end{array}$ & $\begin{array}{l}\text { Medium } \\
\text { Orange }\end{array}$ & Orange & Yellow & Total & $\begin{array}{l}\text { Test } \\
\text { Ratio }\end{array}$ & $x^{2}$ & $\mathrm{P}$ \\
\hline $\mathrm{F}_{2}$ & Core & 118 & 54 & 57 & 68 & 76 & 58 & 134 & 297 & 431 & $\begin{array}{l}0.45: \\
2.22\end{array}$ & 0.06 & 0.80 \\
\hline $\mathrm{BCP}_{1}$ & Core & 20 & 11 & 14 & 12 & 28 & 34 & 62 & 57 & 119 & $\begin{array}{l}\text { 1.09: } \\
0.92\end{array}$ & 0.21 & 0.64 \\
\hline $\mathrm{BCP}_{2}$ & Core & 24 & 16 & 13 & 14 & 34 & 18 & 52 & 67 & 119 & $\begin{array}{l}0.78: \\
1.29\end{array}$ & 1.01 & 0.31 \\
\hline \multicolumn{14}{|c|}{ Pusa Meghali $\left(P_{1}\right) \times$ Pusa Kulfi $\left(P_{2}\right)$} \\
\hline Population & Traits & $\begin{array}{l}\text { Yellow } \\
\text { Orange }\end{array}$ & $\begin{array}{l}\text { Medium } \\
\text { Orange }\end{array}$ & $\begin{array}{l}\text { Light } \\
\text { Orange }\end{array}$ & $\begin{array}{l}\text { Orange } \\
\text { Pink }\end{array}$ & $\begin{array}{l}\text { Yellow } \\
\text { Green }\end{array}$ & $\begin{array}{l}\text { Light } \\
\text { Yellow }\end{array}$ & Orange & Yellow & Total & $\begin{array}{l}\text { Test } \\
\text { Ratio }\end{array}$ & $x^{2}$ & $\mathrm{P}$ \\
\hline $\mathrm{F}_{2}$ & Epiderm & 107 & 64 & 51 & 84 & 47 & 73 & 306 & 306 & 426 & 2.55:0.39 & 0.86 & 0.35 \\
\hline $\mathrm{BCP}_{1}$ & Epiderm & 17 & 12 & 18 & 6 & 33 & 25 & 53 & 53 & 111 & 0.91:1.09 & 0.22 & 0.63 \\
\hline $\mathrm{BCP}_{2}$ & Epiderm & 20 & 10 & 9 & 17 & 22 & 37 & 56 & 60 & 115 & $0.95: 1.05$ & 0.07 & 0.77 \\
\hline $\mathrm{F}_{2}$ & Cortex & 114 & 55 & 67 & 82 & 46 & 62 & 318 & 108 & 426 & $2.94: 0.34$ & 0.02 & 0.86 \\
\hline $\mathrm{BCP}_{1}$ & Cortex & 10 & 18 & 14 & 10 & 21 & 38 & 52 & 59 & 111 & $0.88: 1.13$ & 0.44 & 0.50 \\
\hline $\mathrm{BCP}_{2}$ & Cortex & 18 & 13 & 11 & 14 & 24 & 35 & 56 & 59 & 115 & $0.95: 1.05$ & 0.07 & 0.77 \\
\hline Population & Traits & $\begin{array}{l}\text { Yellow } \\
\text { Green }\end{array}$ & $\begin{array}{l}\text { Light } \\
\text { Yellow }\end{array}$ & $\begin{array}{l}\text { Medium } \\
\text { Yellow }\end{array}$ & Yellow & $\begin{array}{l}\text { Yellow } \\
\text { Orange }\end{array}$ & $\begin{array}{l}\text { Medium } \\
\text { Orange }\end{array}$ & Orange & Yellow & Total & $\begin{array}{l}\text { Test } \\
\text { Ratio }\end{array}$ & $\chi^{2}$ & $\mathrm{P}$ \\
\hline $\mathrm{F}_{2}$ & Core & 107 & 64 & 51 & 84 & 47 & 73 & 120 & 306 & 426 & $\begin{array}{l}0.39: \\
2.55\end{array}$ & 2.28 & 0.13 \\
\hline $\mathrm{BCP}_{1}$ & Core & 17 & 12 & 18 & 6 & 33 & 25 & 58 & 53 & 111 & $\begin{array}{l}\text { 1.09: } \\
0.91\end{array}$ & 0.22 & 0.63 \\
\hline $\mathrm{BCP}_{2}$ & Core & 21 & 16 & 14 & 9 & 29 & 26 & 55 & 60 & 115 & $\begin{array}{l}0.92: \\
1.09\end{array}$ & 0.21 & 0.64 \\
\hline
\end{tabular}




\section{Conclusion}

Cultivated carrot yield diverse carotenoids due to colours assortment in the root aided with the interaction of several genes, the diverse root colours namely orange, yellow and red are associated in the accumulation of carotenoids in the root. It is challenging to compare colours attributed to carotenoid content in the mixed colour segregated in the root, and complex task to understand the cause for variation of mixed carotenoids in the root. To account the causal genes for the variability of carotenoids in the epidermis, cortex and core based on the chi-square test ratio of segregating population were ascertained that the dominant genes are Oe (orange epidermis) and Ocx (orange cortex) from Pusa Meghli, $Y_{c}$ (yellow core) from Pusa Kulfi and $R c$ (red core) from Pusa Rudhira, recessive genes namely oc (orange core) from Pusa Meghli, ye (yellow epidermis) from Pusa Kulfi, re (red epidermis) from Pusa Rudhira, $y c$ (yellow cortex) from Pusa Kulfi and $r c$ (red cortex) Pusa Rudhira were possibly responsible for an assortment of root colour in $\mathrm{F}_{1}, \mathrm{~F}_{2}$, and backcross population. The genetics of root epidermis, cortex and core colour inheritance useful in the accelerating breeding of carotenoids rich varieties and $\mathrm{F}_{1}$ hybrids with uniform mixed root colours.

\section{Abbreviations}

$\mathrm{F}_{1}$ : First filial generation

$\mathrm{F}_{2}$ : Second filial generation of segregating population

$\mathrm{BCP}_{1}$ : Backcross with the male parent to $\mathrm{F}_{1}$

$\mathrm{BCP}_{2}$ : Backcross with the female parent to $\mathrm{F}_{1}$

$\chi^{2}$ : Chi-square test ratio

Ocx: Orange cortex controlled by a dominant gene

Oe: Orange epidermis controlled by a dominant gene

Oc: Orange core controlled by a dominant gene

oc: Orange epidermis controlled by a recessive gene

$R c$ : Red core controlled by a dominant gene

re: Red core controlled by a recessive gene

rcx: Red cortex controlled by a recessive gene

$Y_{C}$. Yellow core controlled by a dominant gene

ycx: Yellow cortex controlled by a recessive gene

\section{Declarations}

Compliance with ethical standards

\section{Ethical Statement}

The manuscript was not submitted elsewhere, and results were presented without falsification, fabrication, or inappropriate data manipulation. Research does not pose any threat to public health or national security.

\section{Conflicts of interest}

We the authors declare no competing interest with the manuscript

\section{Data disposition statement}

\section{Availability of data and material}

The means of experimental data were presented in the form of tables and the inference interpreted in the manuscript. The parental lines and breeding population are available with first author; seed request for research purpose may post to the first author through proper channel.

\section{Funding}


Authors thankful to Indian Agricultural Research Institute for mobilizing the research funds for conducting the experiment at Division of Vegetable Crops, IARI, New Delhi, India, and providing IARI-Senior Research Fellowship for first author.

\section{References}

Arscott SA, Tanumihardjo SA (2010) Carrots of many colours provide basic nutrition and bioavailable phytochemicals acting as a functional food. Compr Rev Food Sci Food Saf 9:223-239.

Banga 0 (1957) Origin of the European cultivated carrot. Euphytica 6:54-63.

Banga O (1963) Main types of the western carotene carrot and their origin. Tjeenk Willink WEJ, Zwolle, The Netherlands.

Borthwick HA,Emsweller SL (1933) Carrot breeding experiments. Proc Am Soc Hortic Sci 30:531-533.

Emsweller SL, Burrell PC, Borthwich HA (1935) Studies on the inheritance of color in carrots. Proc Am Soc Hortic Sci 33:508-511.

Goldman IL, Breitbach DN (1996) Inheritance of a recessive character controlling reduced carotenoid pigmentation in carrot (Daucus carota L.). J Hered 87:380-382

Grassmann J, Schnitzler WH, Habegger R (2007) Evaluation of different coloured carrot cultivars on antioxidative capacity based on their carotenoid and phenolic contents. Int J Food Sci Nutr 58:603-611.

Imam MK, Gabelman WH (1968) Inheritance of carotenoids in carrots, Daucus carota, L. Proc Am Soc Hortic Sci 93:419-428.

Iorizzo M, Senalik DA, Ellison SL et al. (2013) Genetic structure and domestication of carrot (Daucus carota L. subsp. sativus L.) (Apiaceae). Am J Bot 100:930-938.

Katsumata HH, Yasui H, Matsue Y, Hamazaki K (1966) Studies on the premature bolting and carotene, lycopene, content in carrot. Bul Hort Res Stn Japan Ser D 4:107-129.

Kust AF (1970) Inheritance and differential formation of color and associated pigments in xylem and phloem of carrot, Daucus carota, L. Dissertation, University of Wisconsin, Madison.

Laferriere L, Gabelman WH (1968) Inheritance of color, total carotenoids, alpha-carotene, and beta-carotene in carrots, Daucus carota L. Proc Am Soc Hortic Sci 93:408-418.

Lamprecht H, Svensson V (1950) The carotene content of carrots and its relation to various factors. Agri Hort Genet. 8:74-108.

Nicolle C, Simon G, Rock E, Amouroux P, Rémésy C (2004) Genetic variability influences carotenoid, vitamin, phenolic, and mineral content in white, yellow, purple, orange, and dark-orange carrot cultivars. J Am Soc Hortic Sci 129:523-529.

PBT (2005) Plant Breeding Tools: Plant breeding, genetics and biotechnology, International Rice Research Institute, Philippines.

Perrin F, Brahem M, Dubois-Laurent C, et al. (2016) Differential pigment accumulation in carrot leaves and roots during two growing periods. J Agric Food Chem 64:906-912.

Perrin F, Dubois-Laurent C, Gibon Y, Citerne S et al. (2017) Combined Alternaria dauci infection and water stresses impact carotenoid content of carrot leaves and roots. Environ Exp Bot 143:125-134.

RHS (2005) The Royal Horticultural Society Colour Chart. The Royal Horticultural Society, London.

Rubatzky VE, Quiros CF, Simon PW (1999) Carrots and related vegetable Umbelliferae. CABI, New York

Simon PW (2000) Domestication, historical development, and modern breeding of carrot. Plant Breed Rev 19:157-190.

Simon PW, Geoffriau E, Ellison S, lorizzo M (2019) Carrot Carotenoid Genetics and Genomics. In: Simon P, lorizzo M, Grzebelus D, Baranski R (eds) The Carrot Genome. Compendium of Plant Genomes. Springer, Cham. https://doi.org/10.1007/978-3-030-03389-7_14

Simon PW, Wolff XY (1987) Carotenes in typical and dark orange carrots. J Agric Food Chem 35:1017-1022.

Stolarczyk J, Janick J (2011) Carrot: History and iconography. Chron Hortic 51:13-18

Tanumihardjo S (2012) Carotenoids and human health. Springer, New York.

Vilmorin M (1859) L'hérédité dans les végétaux. In: Vilmorin M (ed) Notice sur l'amelioration des plantes par la semis. Librairie Agricole, Paris, France pp 5-29. 


\section{Figures}
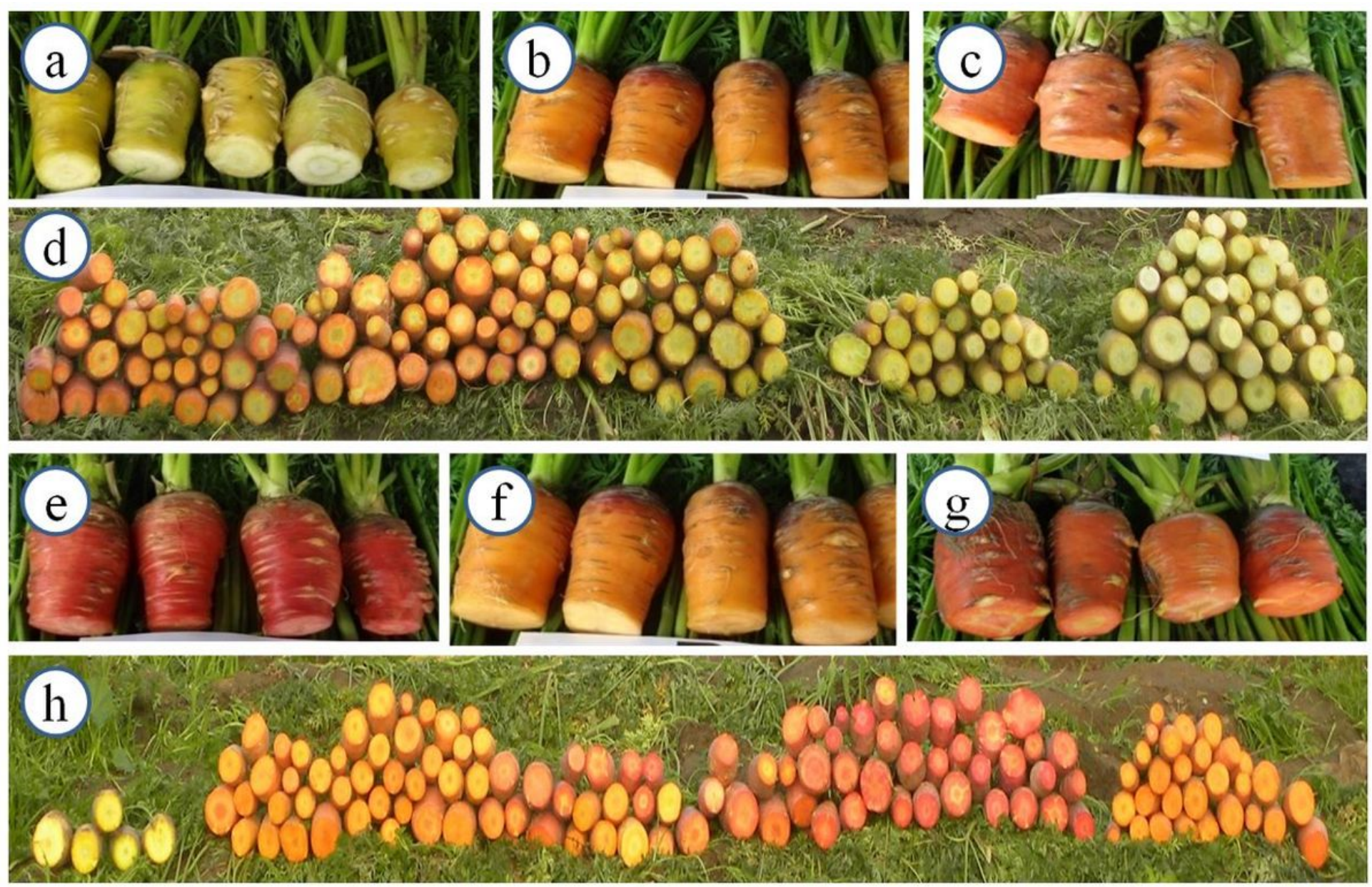

Figure 1

a) Puas Kulfi, b) Puas Meghali, c) F1 Hybrid of Puas Kulfi $\times$ Puas Meghali, d) F2 population developed from the cross Puas Kulfi $\times$ Puas Meghali, e) Puas Rudhira, f) Puas Meghali, g) F1 Hybrid of Puas Rudhira $\times$ Puas Meghali, h) F2 population developed from the cross Puas Rudhira $\times$ Puas Meghali

\section{Image not available with this version}

Figure 2 